\title{
Nutritional status, oxidative stress and dementia: the role of selenium in Alzheimer's disease
}

\author{
Jose R. Santos ${ }^{1 *}$, Auderlan M. Gois ${ }^{2}$, Deise M. F. Mendonça ${ }^{2}$ and Marco A. M. Freire ${ }^{3 *}$ \\ ${ }^{1}$ Department of Biology, Federal University of Sergipe, São Cristóvão, Brazil \\ ${ }^{2}$ Department of Bioscience, Federal University of Sergipe, São Cristóvão, Brazil \\ ${ }^{3}$ Laboratory of Cellular Neurobiology, Edmond and Lily Safra International Institute for Neuroscience of Natal, Natal, Brazil \\ *Correspondence: joseronaldosantos@gmail.com; freire.m@gmail.com
}

Edited by:

Claudia Perez-Cruz, Centro de Investigaciones y Estudios Avanzados CINVESTAV, Mexico

Reviewed by:

Claudia Perez-Cruz, Centro de Investigaciones y Estudios Avanzados CINVESTAV, Mexico

Maxwell Barbosa Santana, Federal University of West Pará, Brazil

Rovena Engelberth, Federal University of Rio Grande do Norte, Brazil

Keywords: dementia, Alzheimer's disease, nutritional status, selenium, oxidative stress

The term dementia derives from the Latin demens ("de": private, "mens": mind, intelligence, judgment—“without a mind"). The American Psychiatric Association (APA) describes it as "any mental impairment, or global cognitive decline in a previously unimpaired person" and is characterized by a deterioration of cognitive, intellectual, emotional, and behavioral skills, severe enough to interfere with the daily life of its sufferers (APA, 1994). It may be elicited by pathologies related to aging, stroke and mechanical injury, or by recurrent use of alcohol and substance abuse, including smoking (DeKosky et al., 2010; Rojas et al., 2010; Brown and Thore, 2011; Rusanen et al., 2011).

Dementias are far more prevalent in the elderly, since only about $5 \%$ of all reported cases involve people under 65 yearsold, the so-called "early onset dementias" (Fadil et al., 2009). In the United States of America, the prevalence of dementia in individuals aging 90 or over exceeds 37\% (Plassman et al., 2007). According to estimates from the Alzheimer's Disease International (ADI), about 36 million people around the world are currently suffering from some sort of dementia and this number was predicted to be at least three times higher in 2050 (ADI, 2010). Approximately two-thirds of all people with dementia live in less developed regions, and these disorders are considered a major burden for health care and social systems in developing countries (Wimo et al., 2003).
Alzheimer's disease (AD) is the major senile dementia, defined as a degenerative, progressive, and irreversible disorder, characterized by a gradual loss of cognitive function and by behavioral disturbances. It most commonly afflicts individuals over 65 years old, accounting for more than half of every worldwide dementia cases (LoGiudice, 2002). AD progression can be ranked into three stages. At the early stage, the patient has difficulty in thinking clearly, presenting a concomitant decrease in performance in complex tasks. At the moderate stage, aphasia is evident-inefficiency in naming objects or to choose the right word to express an idea. In the severe stage, there are prominent changes in the sleep-wake cycle, psychotic symptoms, and in the abilities to walk, talk, and self-care (Herrera-Rivero et al., 2010). Individuals become strictly dependent of caregivers and their condition deteriorates when psychiatric symptoms or often disruptive behavioral changes develop, imposing greater burden to the caregivers. Death usually occurs 3-9 years after the onset of symptoms (Querfurth and LaFerla, 2010).

Currently there is no effective treatment to $\mathrm{AD}$ and its cause (or causes) remains to be defined, although factors such as family history, diet, lifestyle, genetics, and head injury have been suggested. Familial $\mathrm{AD}$ involves mutations in the amyloid precursor protein and presenilins 1 and 2 (Rogaev et al., 1995; El Kadmiri et al., 2013), which cause overproduction of the $\beta$-amyloid protein. Moreover, increased levels of cholesterol, hypertension, and diabetes are also involved in $\mathrm{AD}$ development (Bassil and Mollaei, 2012; Wirz et al., 2014). An interdependence between cholesterol metabolism, Apolipoprotein E genotype and $\beta$-amyloid metabolic pathway has been reported, with implications to the pathogenesis of $\mathrm{AD}$ (Evans et al., 2004). Clinical findings suggest a lower risk of $\mathrm{AD}$ in individuals using statins in order to reduce their cholesterol levels (Shepardson et al., 2011).

A common condition in $\mathrm{AD}$ patients is weight loss, due to malnourishment induced by poor diet during the progression of the disease and the gradual impotence of feeding appropriately. A healthy nutrition, based on the correct selection and amount of micronutrients, contributes to delaying the cognitive decline both during aging and in $\mathrm{AD}$ patients (Lee et al., 2009; Spaccavento et al., 2009; Hadziabdic et al., 2012). Specific foods and diets have been reported to lower the risk of AD (Steele et al., 2007). The Mediterranean diet is based on a dietary pattern of high consumption of plant foods (fruits, vegetables, cereals, and nuts), olive oil as the main source of fat, a moderate intake of fish, and a low consumption of red meat. It is thus rich in omega-3 fatty acids, antioxidants and vitamins, especially $\mathrm{B}, \mathrm{C}$, and $\mathrm{E}$ (Willett et al., 1995). Antioxidant species are particularly important to help maintain the proper function of the brain (GomezPinilla, 2008; Polidori et al., 2009), and their regular intake reduces oxidative stress 
(Steele et al., 2007; Otaegui-Arrazola et al., 2014).

Oxidative stress is a major harmful factor during aging and pathological conditions (Finkel and Holbrook, 2000; Freire, 2012). It is involved in the onset and progression of several neurodegenerative disorders, such as multiple sclerosis (Clausen et al., 1988; Gilgun-Sherki et al., 2004), amyotrophic lateral sclerosis (Baillet et al., 2010; Dias et al., 2013), Batten's disease (Clausen et al., 1988), Parkinson's disease (Freire and Santos, 2010; Dias et al., 2013), and AD (Markesbery, 1997; Pratico, 2008; Zhao and Zhao, 2013). Oxidative stress results from an imbalance between the levels of reactive oxygen species (ROS) and endogenous antioxidant mechanisms (Nunomura, 2013; Padurariu et al., 2013), which causes structural and functional impairment of cells by degrading lipids, proteins, and nucleic acids (Reynolds et al., 2007), and ultimately results in cell death.

NADPH oxidase (NOX) is one of the major enzymes involved in the process of oxidative stress. Its overexpression is induced especially by microglial activation in the brain in both acute (Block et al., 2007) and chronic conditions (Wu et al., 2003). NOX seems to play a role in $\mathrm{AD}$, especially by the action of NOX2, which is upregulated in the brain of $\mathrm{AD}$ patients (Shimohama et al., 2000; Zekry et al., 2003). NOX2 expression is induced by the presence of $\beta$-amyloid plaques that stimulate the activation of microglial NOX leading to superoxide production (Wilkinson et al., 2012), which in turn leads to mitochondrial disfunction (Guimaraes et al., 2009), cleavage of nucleic acids (Nunomura et al., 2012), and proteolysis (Esler and Wolfe, 2001). There is a direct relationship between the impairment of cognitive performance of $\mathrm{AD}$ patients and the increase of NOX activity (Ansari and Scheff, 2012).

Glutathione peroxidase (GSH-Px) is a free radical scavenger and a key-enzyme in the endogenous defensive mechanism against free radicals (Chen and Berry, 2003). Its main role is to protect cells from ROS by inactivating hydrogen peroxides and lipid hydroperoxides originated during oxidative metabolism (Arthur, 2000). Accordingly, the decrease of GSH-Px activity leads to tissue damage and cell death due to detrimental action of ROS in increased levels. GSH-Px mechanism of action is based on the redox ability of thiol groups of glutathione and the catalytic reduction of peroxides, either inorganic (hydrogen peroxide) or organic (lipid peroxides). Its functioning is seleniumdependent (Ceballos-Picot et al., 1996), and a low dietary intake of this element alters GSH-Px activity (Arthur, 2000).

Selenium (Se) is micronutrient important to the maintenance of human health, and acts on immune defense, thyroid gland and cardiovascular functions, and cancer prevention (Finley, 2003; Thomson et al., 2009; Joseph and Loscalzo, 2013). Its deficiency results in cardiomyopathy associated to Keshan disease in children (Loscalzo, 2014), a pathology especially observed in regions where the soil is Sedeficient. As stated above, Se acts as an antioxidant component, working in combination with GSH-Px. They protect lipids by catalyzing the reduction of hydrogen peroxide and phospholipid hydroperoxides generated in vivo by ROS (Gamble et al., 1997).

Se main natural sources are bread, cereals, seafood, cruciferous vegetables (mainly broccoli) (Finley, 2005; Finley et al., 2005), and especially Brazil nut (Thomson et al., 2008). In an interesting study, Thomson et al. (2008) showed that the insertion of two units of Brazil nuts daily for 12 weeks in the diet increases Se levels in the humans' organism and enhances GSH-Px activity. In an animal model of Parkinson's disease, the systemic administration of Se improved antioxidant activity, protecting dopaminergic cells from the deleterious effects of 6hydroxydopamine (Zafar et al., 2003), reinforcing the notion of its action in the redox balance in the brain. Se also combines with amino acids to form small peptides called selenoproteins (Papp et al., 2010), which exert antioxidant activities as enzymes (Takemoto et al., 2010; Zhang et al., 2010) and help block ROS involved in cell collapse, as it is seen in $\mathrm{AD}$ (Filipcik et al., 2006).

The physiological actions of micronutrients can be enhanced by their association with vitamins, which also play a significant role in reducing oxidative stress in the brain (Morris et al., 1998; Heo et al., 2013; Dysken et al., 2014). In this context, two vitamins are particularly important: vitamin C (ascorbic acid), considered the most important soluble antioxidant, able to neutralize ROS before the initiation of lipid peroxidation (Heo et al., 2013); and vitamin E, an important liposoluble antioxidant that is beneficial particularly at the membrane level, protecting polyunsaturated fatty acids from peroxidation (Tewari et al., 2014). The ingestion of high-dose vitamins $\mathrm{E}$ and $\mathrm{C}$ supplements may lower the risk of $\mathrm{AD}(\mathrm{Li}$ et al., 2012; Heo et al., 2013; Dysken et al., 2014).

The clear-cut effects of dietary intake on overall health is well-established (Vermeer et al., 2003), and evidence suggests that nutritional deficiency contributes to the development of neuropathological conditions (Gillman et al., 1995). In a recent meta-analysis, Li et al. (2012) concluded that clinical studies about dietary intake of vitamins E, C, and $\beta$-carotene point to a positive role of these elements in prevention and interventional treatment of AD. Regarding Se, studies in humans confirm its participation in the prevention and treatment of brain disorders, either isolated or in combination with other elements (Sanmartin et al., 2011). Smorgon et al. (2004) described a direct correlation between the reduced Se plasma concentration and the decline of cognitive function in $\mathrm{AD}$ patients when compared to healthy individuals. Such event can be related to the process of oxidative stress reported in AD. Accordingly, in a recent study Olde Rikkert et al. (2014) found lower levels of Se in the plasma of non-malnourished patients in the early stage of $\mathrm{AD}$ when compared to healthy controls, suggesting that differences in nutritional status are present in $\mathrm{AD}$ even in the absence of malnutrition (Smorgon et al., 2004; Cardoso et al., 2010; Vural et al., 2010; Olde Rikkert et al., 2014).

Nonetheless, despite the correlations between some nutrients and cognitive function, more research has yet to be realized about the likely wide-ranging impact of nutrition and its benefits to neurodegenerative diseases. Overall, a diet including minerals and vitamins, especially associated to physical activity, importantly contributes to the attenuation of oxidative stress in the brain (Ma, 2008; Morris, 2009; van Praag, 2009). 
In addition, it is important to remark that the improvement of general nutritional status should be preferably based on food sources instead of alternative supplementation practices, since the formers are more accessible, sustainable, and present lower risk of toxicity than the latters (Finley, 2005).

\section{ACKNOWLEDGMENT}

Marco A. M. Freire is supported by Associação Alberto Santos Dumont para Apoio a Pesquisa (AASDAP)—Brazil.

\section{REFERENCES}

ADI. (2010). World Alzheimer Report. The Global Economic Impact of Dementia. London: Alzheimer's Disease International. Available online at: http://www.alz.co.uk/research/files/World AlzheimerReport2010ExecutiveSummary.pdf

Ansari, M. A., and Scheff, S. W. (2012). NADPHoxidase activation and cognition in Alzheimer disease progression. Free Radic. Biol. Med. 51, 171-178. doi: 10.1016/j.freeradbiomed.2011. 03.025

Arthur, J. R. (2000). The glutathione peroxidases. Cell. Mol. Life Sci. 57, 1825-1835. doi: 10.1007/PL00000664

APA. (1994). American Psychiatric Association: Diagnostic and Statistical Manual of Mental Disorders, 4th Edn. Washington, DC: American Psychiatric Association.

Baillet, A., Chanteperdrix, V., Trocme, C., Casez, P., Garrel, C., and Besson, G. (2010). The role of oxidative stress in amyotrophic lateral sclerosis and Parkinson's disease. Neurochem. Res. 35, 1530-1537. doi: 10.1007/s11064-010-0212-5

Bassil, N., and Mollaei, C. (2012). Alzheimer's dementia: a brief review. J. Med. Liban. 60, 192-199. Available online at: http://lebaneseme dicaljournal.org/articles/60-4/review2.pdf

Block, M. L., Zecca, L., and Hong, J. S. (2007). Microglia-mediated neurotoxicity: uncovering the molecular mechanisms. Nat. Rev. Neurosci. 8, 57-69. doi: $10.1038 / \mathrm{nrn} 2038$

Brown, W. R., and Thore, C. R. (2011). Review: cerebral microvascular pathology in aging and neurodegeneration. Neuropathol. Appl. Neurobiol. 37, 56-74. doi: 10.1111/j.1365-2990.2010.01139.x

Cardoso, B. R., Ong, T. P., Jacob-Filho, W., Jaluul, O., Freitas, M. I., and Cozzolino, S. M. (2010). Nutritional status of selenium in Alzheimer's disease patients. Br. J. Nutr. 103, 803-806. doi: $10.1017 /$ S0007114509992832

Ceballos-Picot, I., Merad-Boudia, M., Nicole, A., Thevenin, M., Hellier, G., Legrain, S., et al. (1996). Peripheral antioxidant enzyme activities and selenium in elderly subjects and in dementia of Alzheimer's type-place of the extracellular glutathione peroxidase. Free Radic. Biol. Med. 20, 579-587. doi: 10.1016/0891-5849(95)02058-6

Chen, J., and Berry, M. J. (2003). Selenium and selenoproteins in the brain and brain diseases. J. Neurochem. 86, 1-12. doi: 10.1046/j.14714159.2003.01854.x
Clausen, J., Jensen, G. E., and Nielsen, S. A (1988). Selenium in chronic neurologic diseases. Multiple sclerosis and Batten's disease. Biol. Trace Elem. Res. 15, 179-203. doi: 10.1007/ BF02990136

DeKosky, S. T., Ikonomovic, M. D., and Gandy, S. (2010). Traumatic brain injury - football, warfare, and long-term effects. N. Engl. J. Med. 363, 1293-1296. doi: 10.1056/NEJMp1007051

Dias, V., Junn, E., and Mouradian, M. M. (2013). The role of oxidative stress in Parkinson's disease. J. Parkinsons Dis. 3, 461-491. doi: 10.3233/JPD130230

Dysken, M. W., Sano, M., Asthana, S., Vertrees, J. E., Pallaki, M., Llorente, M., et al. (2014). Effect of vitamin $\mathrm{E}$ and memantine on functional decline in Alzheimer disease: the TEAM-AD VA cooperative randomized trial. JAMA 311, 33-44. doi: 10.1001/jama.2013.282834

El Kadmiri, N., Hamzi, K., El Moutawakil, B., Slassi, I., and Nadifi, S. (2013). Genetic aspects of Alzheimer's disease (Review). Pathol. Biol. 61, 228-238. doi: 10.1016/j.patbio.2013.04.001

Esler, W. P., and Wolfe, M. S. (2001). A portrait of Alzheimer secretases-new features and familiar faces. Science 293, 1449-1454. doi: 10.1126/science. 1064638

Evans, R. M., Hui, S., Perkins, A., Lahiri, D. K., Poirier, J., and Farlow, M. R. (2004). Cholesterol and APOE genotype interact to influence Alzheimer disease progression. Neurology 62, 1869-1871. doi: 10.1212/01.WNL.0000125323.15458.3F

Fadil, H., Borazanci, A., Ait Ben Haddou, E., Yahyaoui, M., Korniychuk, E., Jaffe, S. L., et al. (2009). Early onset dementia. Int. Rev. Neurobiol. 84, 245-262. doi: 10.1016/S0074-7742(09)00413-9

Filipcik, P., Cente, M., Ferencik, M., Hulin, I., and Novak, M. (2006). The role of oxidative stress in the pathogenesis of Alzheimer's disease. Bratisl. Lek. Listy 107, 384-394. Available online at: http://www.bmj.sk/2006/107910-08.pdf

Finkel, T., and Holbrook, N. J. (2000). Oxidants, oxidative stress and the biology of ageing. Nature 408, 239-247. doi: 10.1038/35041687

Finley, J. W. (2003). Reduction of cancer risk by consumption of selenium-enriched plants: enrichment of broccoli with selenium increases the anticarcinogenic properties of broccoli. J. Med. Food 6 , 19-26. doi: 10.1089/109662003765184714

Finley, J. W. (2005). Selenium accumulation in plant foods. Nutr. Rev. 63, 196-202. doi: 10.1111/j.17534887.2005.tb00137.x

Finley, J. W., Sigrid-Keck, A., Robbins, R. J., and Hintze, K. J. (2005). Selenium enrichment of broccoli: interactions between selenium and secondary plant compounds. J. Nutr. 135, 1236-1238. Available online at: http://jn.nutrition.org/ content/135/5/1236.full.pdf+html

Freire, M. A. M. (2012). Pathophysiology of neurodegeneration following traumatic brain injury. West Indian Med. J. 61, 751-755. doi: 10.7727/wimj. 2012.003

Freire, M. A. M., and Santos, J. R. (2010). Parkinson's disease: general features, effects of levodopa treatment and future directions. Front. Neuroanat. 4:146. doi: $10.3389 /$ fnana.2010.00146

Gamble, S. C., Wiseman, A., and Goldfarb, P. S. (1997). Selenium-dependent glutathione peroxidase and other selenoproteins: their synthesis and biochemical roles. J. Chem. Tech. Biotechnol. 68, 123-134.

Gilgun-Sherki, Y., Melamed, E., and Offen, D. (2004). The role of oxidative stress in the pathogenesis of multiple sclerosis: the need for effective antioxidant therapy. J. Neurol. 251, 261-268. doi: 10.1007/s00415-004-0348-9

Gillman, M. W., Cupples, L. A., Gagnon, D., Posner, B. M., Ellison, R. C., Castelli, W. P., et al. (1995). Protective effect of fruits and vegetables on development of stroke in men. JAMA 273, 1113-1117. doi: 10.1001/jama.1995.03520380049034

Gomez-Pinilla, F. (2008). Brain foods: the effects of nutrients on brain function. Nat. Rev. Neurosci. 9 , 568-578. doi: 10.1038/nrn2421

Guimaraes, J. S., Freire, M. A. M., Lima, R. R., Souza-Rodrigues, R. D., Costa, A. M., dos Santos, C. D., et al. (2009). Mechanisms of secondary degeneration in the central nervous system during acute neural disorders and white matter damage. Rev. Neurol. 48, 304-310. Available online at: http://www.neurologia.com/pdf/Web/4806/ bb060304_ENGLISH.pdf

Hadziabdic, M. O., Bozikov, V., Pavic, E., and Romic, Z. (2012). The antioxidative protecting role of the Mediterranean diet. Coll. Antropol. 36, 1427-1434. Available online at: hrcak.srce.hr/file/139871

Heo, J. H., Hyon, L., and Lee, K. M. (2013). The possible role of antioxidant vitamin $\mathrm{C}$ in Alzheimer's disease treatment and prevention. Am. J. Alzheimers Dis. Other Demen. 28, 120-125. doi: $10.1177 / 1533317512473193$

Herrera-Rivero, M., Hernandez-Aguilar, M. E. Manzo, J., and Aranda-Abreu, G. E. (2010). Alzheimer's disease: immunity and diagnosis. Rev. Neurol. 51, 153-164. Available online at: http://www.neurologia.com/pdf/Web/5103/ be030153.pdf

Joseph, J., and Loscalzo, J. (2013). Selenistasis: epistatic effects of selenium on cardiovascular phenotype. Nutrients 5, 340-358. doi: 10.3390/nu5020340

Lee, K. S., Cheong, H. K., Kim, E. A., Kim, K. R., Oh, B. H., and Hong, C. H. (2009). Nutritional risk and cognitive impairment in the elderly. Arch. Gerontol. Geriatr. 48, 95-99. doi: 10.1016/j.archger. 2007.11.001

Li, F. J., Shen, L., and Ji, H. F. (2012). Dietary intakes of vitamin $\mathrm{E}$, vitamin $\mathrm{C}$, and beta-carotene and risk of Alzheimer's disease: a meta-analysis. J. Alzheimers. Dis. 31, 253-258. doi: 10.3233/JAD2012-120349

LoGiudice, D. (2002). Dementia: an update to refresh your memory. Intern. Med. J. 32, 535-540. doi: 10.1046/j.1445-5994.2002.00294.x

Loscalzo, J. (2014). Keshan disease, selenium deficiency, and the selenoproteome. N. Engl. J. Med 370, 1756-1760. doi: 10.1056/NEJMcibr 1402199

$\mathrm{Ma}, \mathrm{Q}$. (2008). Beneficial effects of moderate voluntary physical exercise and its biological mechanisms on brain health. Neurosci. Bull. 24, 265-270. doi: 10.1007/s12264-008-0402-1

Markesbery, W. R. (1997). Oxidative stress hypothesis in Alzheimer's disease. Free Radic. Biol. Med. 23, 134-147. doi: 10.1016/S0891-5849(96)00629-6

Morris, M. C. (2009). The role of nutrition in Alzheimer's disease: epidemiological evidence. Eur. J. Neurol. 16(Suppl. 1), 1-7. doi: 10.1111/j.14681331.2009.02735.x 
Morris, M. C., Beckett, L. A., Scherr, P. A., Hebert, L. E., Bennett, D. A., Field, T. S., et al. (1998). Vitamin E and vitamin C supplement use and risk of incident Alzheimer disease. Alzheimer Dis. Assoc. Disord. 12, 121-126. doi: 10.1097/00002093199809000-00001

Nunomura, A. (2013). Oxidative stress hypothesis for Alzheimer's disease and its potential therapeutic implications. Rinsho Shinkeigaku 53, 1043-1045. doi: 10.5692/clinicalneurol.53.1043

Nunomura, A., Moreira, P. I., Castellani, R. J., Lee, H. G., Zhu, X., Smith, M. A., et al. (2012). Oxidative damage to RNA in aging and neurodegenerative disorders. Neurotox. Res. 22, 231-248. doi: 10.1007/s12640-012-9331-x

Olde Rikkert, M. G., Verhey, F. R., Sijben, J. W., Bouwman, F. H., Dautzenberg, P. L., Lansink, M., et al. (2014). Differences in nutritional status between very mild Alzheimer's disease patients and healthy controls. J. Alzheimers Dis. 41, 261-271. doi: 10.3233/JAD-131892

Otaegui-Arrazola, A., Amiano, P., Elbusto, A., Urdaneta, E., and Martinez-Lage, P. (2014). Diet, cognition, and Alzheimer's disease: food for thought. Eur. J. Nutr. 53, 1-23. doi: 10.1007/s00394-013-0561-3

Padurariu, M., Ciobica, A., Lefter, R., Serban, I. L., Stefanescu, C., and Chirita, R. (2013). The oxidative stress hypothesis in Alzheimer's disease. Psychiatr. Danub. 25, 401-409. Available online at: http://www.hdbp.org/psychiatria_danubina/ pdf/dnb_vol25_no4/dnb_vol25_no4_401.pdf

Papp, L. V., Holmgren, A., and Khanna, K. K. (2010). Selenium and selenoproteins in health and disease. Antioxid. Redox Signal. 12, 793-795. doi: 10.1089/ars.2009.2973

Plassman, B. L., Langa, K. M., Fisher, G. G., Heeringa, S. G., Weir, D. R., Ofstedal, M. B., et al. (2007). Prevalence of dementia in the United States: the aging, demographics, and memory study. Neuroepidemiology 29, 125-132. doi: 10.1159/ 000109998

Polidori, M. C., Pratico, D., Mangialasche, F., Mariani, E., Aust, O., Anlasik, T., et al. (2009). High fruit and vegetable intake is positively correlated with antioxidant status and cognitive performance in healthy subjects. J. Alzheimers Dis. 17, 921-927. doi: 10.3233/JAD-2009-1114

Pratico, D. (2008). Oxidative stress hypothesis in Alzheimer's disease: a reappraisal. Trends Pharmacol. Sci. 29, 609-615. doi: 10.1016/j.tips. 2008.09.001

Querfurth, H. W., and LaFerla, F. M. (2010). Alzheimer's disease. N. Engl. J. Med. 362, 329-344. doi: 10.1056/NEJMra0909142

Reynolds, A., Laurie, C., Mosley, R. L., and Gendelman, H. E. (2007). Oxidative stress and the pathogenesis of neurodegenerative disorders. Int. Rev. Neurobiol. 82, 297-325. doi: 10.1016/S0074-7742(07)82016-2

Rogaev, E. I., Sherrington, R., Rogaeva, E. A., Levesque, G., Ikeda, M., Liang, Y., et al. (1995). Familial Alzheimer's disease in kindreds with missense mutations in a gene on chromosome 1 related to the Alzheimer's disease type 3 gene. Nature 376, 775-778. doi: 10.1038/ $376775 \mathrm{a} 0$

Rojas, G., Serrano, C., Dillon, C., Bartoloni, L., Iturry, M., and Allegri, R. F. (2010). Use and abuse of drugs in cognitive impairment patients. Vertex 21, 18-23. Available online at: http://europepmc.org/abstract/med/20440408

Rusanen, M., Kivipelto, M., Quesenberry, C. P. Jr., Zhou, J., and Whitmer, R. A. (2011). Heavy smoking in midlife and long-term risk of Alzheimer disease and vascular dementia. Arch. Intern. Med. 171, 333-399. doi: 10.1001/archinternmed. 2010.393

Sanmartin, C., Plano, D., Font, M., and Palop J. A. (2011). Selenium and clinical trials: new therapeutic evidence for multiple diseases. Curr. Med. Chem. 18, 4635-4650. doi: 10.2174/0929867 11797379249

Shepardson, N. E., Shankar, G. M., and Selkoe, D. J. (2011). Cholesterol level and statin use in Alzheimer disease: I. Review of epidemiological and preclinical studies. Arch. Neurol. 68, 1239-1244. doi: 10.1001/archneurol.2011.203

Shimohama, S., Tanino, H., Kawakami, N., Okamura, N., Kodama, H., Yamaguchi, T., et al. (2000). Activation of NADPH oxidase in Alzheimer's disease brains. Biochem. Biophys. Res. Commun. 273 5-9. doi: 10.1006/bbrc.2000.2897

Smorgon, C., Mari, E., Atti, A. R., Dalla Nora, E., Zamboni, P. F., Calzoni, F., et al. (2004). Trace elements and cognitive impairment: an elderly cohort study. Arch. Gerontol. Geriatr. Suppl. 9, 393-402. doi: 10.1016/j.archger.2004.04.050

Spaccavento, S., Del Prete, M., Craca, A., and Fiore, P. (2009). Influence of nutritional status on cognitive, functional and neuropsychiatric deficits in Alzheimer's disease. Arch. Gerontol. Geriatr. 48, 356-360. doi: 10.1016/j.archger.2008. 03.002

Steele, M., Stuchbury, G., and Munch, G. (2007). The molecular basis of the prevention of Alzheimer's disease through healthy nutrition. Exp. Gerontol. 42, 28-36. doi: 10.1016/j.exger.2006.06.002

Takemoto, A. S., Berry, M. J., and Bellinger, F. P. (2010). Role of selenoprotein P in Alzheimer's disease. Ethn. Dis. 20, S1-92-95. Available online at: http://www.ncbi.nlm.nih.gov/pmc/articles/ PMC2917322/pdf/nihms-220630.pdf

Tewari, A., Mahendru, V., Sinha, A., and Bilotta, F. (2014). Antioxidants: the new frontier for translational research in cerebroprotection. J. Anaesthesiol. Clin. Pharmacol. 30, 160-171. doi: 10.4103/0970-9185.130001

Thomson, C. D., Campbell, J. M., Miller, J., Skeaff, S. A., and Livingstone, V. (2009). Selenium and iodine supplementation: effect on thyroid function of older New Zealanders. Am. J. Clin. Nutr. 90, 1038-1046. doi: 10.3945/ajcn.2009.28190

Thomson, C. D., Chisholm, A., McLachlan, S. K. and Campbell, J. M. (2008). Brazil nuts: an effective way to improve selenium status. Am. J. Clin. Nutr. 87, 379-384. Available online at: http://ajcn. nutrition.org/content/87/2/379.full.pdf + html

van Praag, H. (2009). Exercise and the brain: something to chew on. Trends Neurosci. 32, 283-290. doi: 10.1016/j.tins.2008.12.007

Vermeer, S. E., Prins, N. D., den Heijer, T., Hofman, A. Koudstaal, P. J., and Breteler, M. M. (2003). Silent brain infarcts and the risk of dementia and cognitive decline. N. Eng. J. Med. 348, 1215-1222. doi: 10.1056/NEJMoa022066

Vural, H., Demirin, H., Kara, Y., Eren, I., and Delibas, N. (2010). Alterations of plasma magnesium, copper, zinc, iron and selenium concentrations and some related erythrocyte antioxidant enzyme activities in patients with Alzheimer's disease. J. Trace Elem. Med. Biol. 24, 169-173. doi: 10.1016/j.jtemb.2010.02.002

Wilkinson, B. L., Cramer, P. E., Varvel, N. H., ReedGeaghan, E., Jiang, Q., Szabo, A., et al. (2012) Ibuprofen attenuates oxidative damage through NOX2 inhibition in Alzheimer's disease. Neurobiol. Aging 33, 197.e121-197.e 132. doi: 10.1016/j. neurobiolaging.2010.06.014

Willett, W. C., Sacks, F., Trichopoulou, A., Drescher, G., Ferro-Luzzi, A., Helsing, E., et al. (1995). Mediterranean diet pyramid: a cultural model for healthy eating. Am. J. Clin. Nutr. 61, 1402S-1406S.

Wimo, A., Winblad, B., Aguero-Torres, H., and von Strauss, E. (2003). The magnitude of dementia occurrence in the world. Alzheimer Dis. Assoc. Dis. 17, 63-67. doi: 10.1097/00002093-20030400000002

Wirz, K. T., Keitel, S., Swaab, D. F., Verhaagen, J., and Bossers, K. (2014). Early molecular changes in Alzheimer disease: can we catch the disease in its presymptomatic phase? J. Alzheimers Dis. 38, 719-740. doi: 10.3233/JAD-130920

Wu, D. C., Teismann, P., Tieu, K., Vila, M., JacksonLewis, V., Ischiropoulos, H., et al. (2003). NADPH oxidase mediates oxidative stress in the 1-methyl4-phenyl-1,2,3,6-tetrahydropyridine model of Parkinson's disease. Proc. Natl. Acad. Sci. U.S.A. 100, 6145-6150. doi: 10.1073/pnas.0937239100

Zafar, K. S., Siddiqui, A., Sayeed, I., Ahmad, M., Salim, S., and Islam, F. (2003). Dose-dependent protective effect of selenium in rat model of Parkinson's disease: neurobehavioral and neurochemical evidences. J. Neurochem. 84, 438-446. doi: 10.1046/j.1471-4159.2003.01531.x

Zekry, D., Epperson, T. K., and Krause, K. H. (2003). A role for NOX NADPH oxidases in Alzheimer's disease and other types of dementia? IUBMB Life 55, 307-313. doi: 10.1080/1521654031000153049

Zhang, S., Rocourt, C., and Cheng, W. H. (2010). Selenoproteins and the aging brain. Mech. Ageing Dev. 131, 253-260. doi: 10.1016/j.mad.2010.02.006

Zhao, Y., and Zhao, B. (2013). Oxidative stress and the pathogenesis of Alzheimer's disease. Oxid. Med. Cell. Longev. 2013:316523. doi: $10.1155 / 2013 / 316523$

Conflict of Interest Statement: The authors declare that the research was conducted in the absence of any commercial or financial relationships that could be construed as a potential conflict of interest.

Received: 17 January 2014; accepted: 25 July 2014; published online: 28 August 2014.

Citation: Santos JR, Gois AM, Mendonça DMF and Freire MAM (2014) Nutritional status, oxidative stress and dementia: the role of selenium in Alzheimer's disease. Front. Aging Neurosci. 6:206. doi: 10.3389/fnagi. 2014.00206

This article was submitted to the journal Frontiers in Aging Neuroscience.

Copyright (C) 2014 Santos, Gois, Mendonça and Freire. This is an open-access article distributed under the terms of the Creative Commons Attribution License (CC BY). The use, distribution or reproduction in other forums is permitted, provided the original author(s) or licensor are credited and that the original publication in this journal is cited, in accordance with accepted academic practice. No use, distribution or reproduction is permitted which does not comply with these terms. 